\title{
Vae Victis! Spatial Planning in the Rescaled Metropolitan Governance in France
}

\author{
Anna Geppert ${ }^{1}$ (D)
}

Received: 11 April 2016 / Accepted: 5 May 2017 / Published online: 7 June 2017

(c) Springer-Verlag Berlin Heidelberg 2017

\begin{abstract}
The paper focuses on the gap between the expectations and the effects of the recent rescaling of planning powers in France. Through a series of legislative reforms in 2010, 2014 and 2015, France has introduced "metropolises". Designed for large cities of more than 500,000 inhabitants, metropolises are a new way of grouping municipalities (Etablissement Public de Coopération Intercommunale), more integrated than the previous bodies which they replace (communauté urbaine, communauté d'agglomération). With enlarged territories and increased decisional power, they were expected to become strong collective actors, providing better services for their inhabitants and making better use of their resources. However, the first outcomes of the reform do not meet these expectations. Metropolises are often smaller than expected. Their perimeters result more from political bargains than from geographical considerations. The emergence of a collective metropolitan power is slowed down by the mayors, who stick to localist approaches, as well as by the national government. Planning objectives have shifted from a redistributive approach (ensuring balanced territorial development) to a growth-oriented policy (enhancing metropolitan potentials). As a result, central areas are gaining economic weight and autonomy while peripheral areas keep declining: there are winners and losers.
\end{abstract}

Keywords Spatial planning - Territorial reform . Metropolitan governance - Inter-municipal collaboration . Rescaling · France

Prof. Dr. Anna Geppert

anna.geppert@paris-sorbonne.fr

1 Institut de Géographie, Université Paris Sorbonne, 191 rue Saint Jacques, 75005 Paris, France
Vae victis! Räumliche Planung in einer neu skalierten metropolitanen Governance in Frankreich

Zusammenfassung Der Beitrag befasst sich mit der Kluft zwischen den Erwartungen und den Auswirkungen der jüngsten Neuorganisation der Planungshoheiten in Frankreich. Durch eine Reihe legislativer Reformen in den Jahren 2010, 2014 und 2015 wurden „Metropolen“ eingeführt. Konzipiert für Großstädte mit über 500.000 Einwohnern, bieten Metropolen eine neue Möglichkeit, Kommunen zu gruppieren (Etablissement Public de Coopération Intercommunale). Zudem sind sie integrierter als die von ihnen abgelösten Einheiten (communauté urbaine, communauté d'agglomération). Mit ihren größeren räumlichen Umgriffen und mehr Entscheidungsmacht sollten die Metropolen starke kollektive Akteure werden, verbesserte Dienstleistungen für ihre Einwohner erbringen und eine bessere Nutzung der Ressourcen sicherstellen. Die ersten Ergebnisse der Reform entsprechen diesen Erwartungen jedoch nicht. Metropolen sind oft kleiner als erwartet und die räumlichen Zuschnitte sind eher das Ergebnis politischer Verhandlungen als geographischer Überlegungen. Die Entstehung kollektiver metropolitaner Macht wird von den Bürgermeistern, die lokale Ansätze vorziehen, sowie von der nationalen Regierung gebremst. Der Schwerpunkt der Planungsziele gilt jetzt weniger der Umverteilung (das Sicherstellen einer ausgewogenen territorialen Entwicklung), sondern konzentriert sich stärker auf eine wachstumsorientierte Politik (die Steigerung metropolitaner Potenziale). Demzufolge gewinnen zentrale Gebiete wirtschaftliches Gewicht und Autonomie, während die Entwicklung der peripheren Gebiete rückläufig bleibt: Es gibt Gewinner und Verlierer. 
Schlüsselwörter Raumplanung · Territoriale Reform · Metropolitane Governance · Interkommunale Zusammenarbeit $\cdot$ Neuskalierung $\cdot$ Frankreich

\section{Introduction}

The French urban system is characterized by the strong primacy of its capital city. Paris as a world ranking capital city (over 10 million inhabitants) is followed by some ten cities of 500,000 to 1,500,000 inhabitants, much smaller and lacking political weight and economic functions. Only three cities reach a population of one million (Lyon, Marseille and Lille), followed by six regional capitals with above 0.5 million inhabitants. This structure is the corollary of a relatively low population density (116 inhabitants $/ \mathrm{km}^{2}$, half the German density) and the off-shoot of the centralization of political power in modern and contemporary history (Geppert 2015). To date, the capital region is home to some $20 \%$ of the French population but produces some $40 \%$ of the national gross domestic product. Here the headquarters of large companies, highly specialized industries, services with a strong added-value, and higher education and research are concentrated (Rozenblat/Cicille 2003).

French geographers have contrasted this to the balanced and polycentric models of urban settlement found in Germany and the Netherlands (Juillard/Nonn 1976). Spatial planning (aménagement du territoire) was created to reduce these disparities, in particular through developing regional capitals as métropoles d'équilibre (Rochefort 2000; Frémont 2005; Alvergne/Musso 2008; Geppert 2009). Since 2010, the metropolitan issue has found new momentum through institutional reform. France is part of a broader movement: among 275 metropolitan areas of more than 500,000 inhabitants worldwide, 49 underwent metropolitan restructuring between 2001 and 2010. This is twice as many as in the previous decade. From 2011 to 2013, new metropolitan governance bodies kept appearing (OECD 2014: 81). However, most of these metropolitan bodies have no regulatory power, while the French metropolises are an additional institutional level, capable of collecting taxes: at first sight, a strong player.

The French call their institutional design a millefeuille: the more layers of puff pastry, the more cream, the better the cake, until it gets indigestible. France has three levels

Table 1 French institutional levels and geographical units

\begin{tabular}{|c|c|c|c|}
\hline & English & French & Definition \\
\hline \multirow{9}{*}{$\begin{array}{l}\text { Institutional } \\
\text { levels }\end{array}$} & Municipality & Commune & Local level of subnational government \\
\hline & County & Département & Intermediate level of subnational government \\
\hline & Region & Région & Highest level of subnational government \\
\hline & $\begin{array}{l}\text { Municipal group- } \\
\text { ing }\end{array}$ & $\begin{array}{l}\text { Etablissement Public de } \\
\text { Coopération Intercommu- } \\
\text { nale }\end{array}$ & $\begin{array}{l}\text { Collaborative institution established by a group of municipalities, ruled } \\
\text { by an assembly of representatives from the municipalities and a presi- } \\
\text { dent. }\end{array}$ \\
\hline & Syndicate & Syndicat intercommunal & Municipal grouping established for specific purpose(s) \\
\hline & $\begin{array}{l}\text { Community of } \\
\text { municipalities }\end{array}$ & Communauté de communes & $\begin{array}{l}\text { Tax-collecting municipal grouping with a moderate level of financial and } \\
\text { decisional integration, suitable for rural contexts }\end{array}$ \\
\hline & $\begin{array}{l}\text { Community of } \\
\text { agglomeration }\end{array}$ & $\begin{array}{l}\text { Communauté } \\
\text { d'agglomération }\end{array}$ & $\begin{array}{l}\text { Tax-collecting municipal grouping with an intermediate level of finan- } \\
\text { cial and decisional integration, suitable for ordinary cities (over 50,000 } \\
\text { inhabitants) }\end{array}$ \\
\hline & Urban community & Communauté urbaine & $\begin{array}{l}\text { Tax-collecting municipal grouping with an important level of financial } \\
\text { and decisional integration, suitable for big cities (over 500,000 inhabi- } \\
\text { tants or historical status). }\end{array}$ \\
\hline & Metropolis & Métropole & $\begin{array}{l}\text { Tax-collecting municipal grouping with an important size and level of } \\
\text { financial and decisional integration, taking over competences from mu- } \\
\text { nicipalities, counties and regions }\end{array}$ \\
\hline \multirow[t]{2}{*}{$\begin{array}{l}\text { Geographical } \\
\text { units }\end{array}$} & Urban unit & Unité urbaine & $\begin{array}{l}\text { Built-up area characterized by a continuity of built space: a municipality } \\
\text { or a group of municipalities which includes a continuously built up zone } \\
\text { (no gap of more than } 200 \text { meters between two constructions) and at least } \\
2000 \text { inhabitants. }\end{array}$ \\
\hline & Urban area & Aire urbaine & $\begin{array}{l}\text { Functional area characterized by the intensity of daily commuting rela- } \\
\text { tions: a group of adjoining municipalities, without pockets of clear land, } \\
\text { encompassing an urban centre (urban unit) providing at least } 10,000 \\
\text { jobs, and rural districts or urban units (urban periphery), where at least } \\
40 \% \text { of the employed resident population works in the centre or in the } \\
\text { municipalities attracted by this centre. }\end{array}$ \\
\hline
\end{tabular}

\footnotetext{
a see https://www.insee.fr/en/metadonnees/definition/c1501 (March 8, 2017)
}

${ }^{\mathrm{b}}$ see https://www.insee.fr/en/metadonnees/definition/c2070 (March 8, 2017) 
of subnational government: municipalities, counties and regions. In addition, there are municipal groupings, which have become quasi subnational governments (see Table 1). Relations between levels are complex, with overlapping competences and competing policies, described in more detail in Section 2.2. As a result, territorial governance remains wobbly.

France has a long history of reforms aiming to improve its institutional design. The rationales of these reforms are manifold and their objectives have evolved over time. In the early stages, the main aim was to adjust the administrative framework to the logics of space, in particular to the emergence of large urban areas where people live and work, by establishing public entities of the "right size" for spatial planning and territorial management: municipal groupings of territorial collaboration and regions. After the 1982 decentralisation ${ }^{1}$, the debate focused on the clarification of competences and the roles of the (too many) levels of subnational government and the (lack of) efficiency of public policies in this setting. Since the 2000 s, increased international territorial competition and the continued development of the European growth-and-jobs agenda have turned attention towards supporting "big players", powerful territorial entities endowed with both the size and powers necessary to hold their own in the global struggle (Alvergne/Taulelle 2002; DATAR 2003; Jouve/Lefèvre 2004; Geppert 2014).

The series of reforms started since 2010 aims to strengthen two levels intended to become central for spatial planning. The 22 regions have been merged into 13 "big regions" (see Figure 1). The new regions were instituted by a law adopted in January 2015 . $^{2}$ This law explains the intention, which is to "strengthen the regional scale by clarifying competences, but also by giving regions a critical size in terms of geography, demography and economy". ${ }^{3}$ In August 2015, a second law defined the competences of these regions, which are twofold: sustainable spatial planning and economic development. ${ }^{4}$ It is stated that these competences are to be articulated through the role of the new metropolises, which will "enhance the development

\footnotetext{
${ }^{1}$ Following the French revolution of 1789 , France had an extremely centralized organization. This lasted until 1982, when a major decentralization reform transferred a large number of competences to the regional and local levels, including spatial planning and economic development; for a historical approach see Geppert (2015).

2 Loi no 2015-29 du 16 janvier 2015 relative à la délimitation des régions, aux élections régionales et départementales et modifiant le calendrier électoral.

3 Projet de loi no 2015-29 du 16 janvier 2015 relative à la délimitation des régions, aux élections régionales et départementales et modifiant le calendrier électoral: exposé des motifs. French bills (projet de loi) contain the justification for the future law.

${ }^{4}$ Loi no 2015-991 du 7 août 2015 portant nouvelle organisation territoriale de la République (NOTRe).
}

of the largest cities and compete equally with European metropolises". 5

Through this series of reforms, municipal groupings were enlarged. For the biggest cities, a new type of municipal grouping was established: the metropolis. This new type of municipal grouping may take over competences from other levels of government: this is new in the French institutional setting. Controversies and governmental changes have led to several reforms-of-the-reform, through a series of laws in 2014 and 2015. The national government has granted 15 cities the status of metropolis. Contrary to the initial objective of the reform, metropolises are very heterogeneous in terms of size (see Table 2).

According to Neil Brenner, the rescaling of powers that has occurred since the late 1970s in Western Europe follows a neo-liberal agenda by giving birth to a "transformed form of (national) capitalism, not to imply its erosion, withering or demise" (Brenner 2004: 4). Indeed, in France, the state has abandoned its historical role in regional planning, one that made France the ideal-type of the "regional economic approach" in the European compendium of spatial planning systems and policies (European Commission 1997). Metropolises and regions combine competences associated with spatial planning and economic development. Will these two dimensions be equally important or, like Brenner (2004) suggests, will the objective of enhancing local growth capacities prevail?

The methodology used in this paper derives from the chronology of the reforms, which are still too recent to make a reliable assessment of their tangible outcomes in spatial planning. The new metropolitan bodies are only beginning to function and have not shaped their agendas. To understand the potential outcomes of the series of reforms adopted between 2010 and 2015, I will use the following criteria:

First, which territory do the metropolises cover? Is it actually the real-life city-region where people live and work, and if not, what is it? To investigate this dimension, I will compare the perimeters of the metropolises with two statistical units: "urban areas" defined by the percentage of commuters to the core-city, which represent the city-region as functional and relational space; and "urban units", defined as continuously built-up areas, which represent the core agglomeration (see Figure 1). Using this approach, I will reveal who are the "insiders" and the "outsiders" in the new configuration. Second, what capacity will the metropolises have to pursue planning activities? One dimension is the shift of powers from the upper level realized in the new setting. Have the transfers of planning competences from other governmental tiers actually occurred? Inside the metropolis,

\footnotetext{
5 Projet de loi no 2015-991 du 7 août 2015 portant nouvelle organisation territoriale de la République: exposé des motifs.
} 

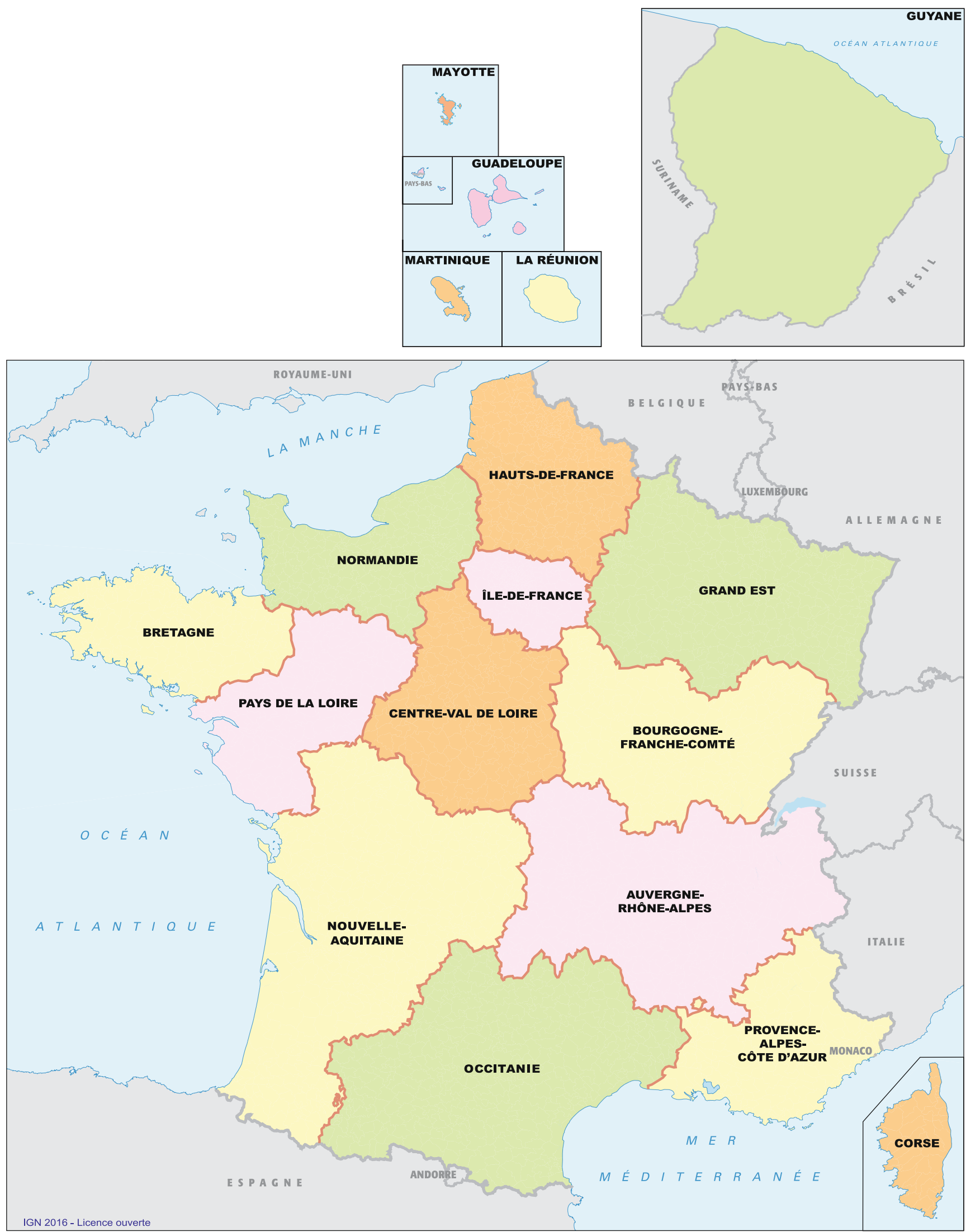

Fig. 1 The new regions established in 2015. (Source: http://education.ign.fr/primaire/fonds-de-cartes (March 8, 2017)) 
Table 2 Metropolises established by July 2016.

(Source: Data from the database BANATIC (Ministry of the Interior, Direction générale des collectivités locales), available on http://www.banatic.interieur. gouv.fr (March 8, 2017). Population based on last census January 1, 2013, summed according to the 2016 municipal groupings)

\begin{tabular}{lll}
\hline Number of municipalities & Name of the grouping & Population \\
131 & Métropole du Grand Paris & $7,041,651$ \\
92 & Métropole d'Aix-Marseille-Provence & $1,876,019$ \\
59 & Métropole de Lyon & $1,281,971$ \\
85 & Métropole Européenne de Lille & $1,145,501$ \\
28 & Bordeaux Métropole & 763,485 \\
37 & Toulouse Métropole & 748,149 \\
24 & Métropole Nantes & 625,118 \\
49 & Métropole Nice Côte d'Azur & 542,891 \\
71 & Métropole Rouen Normandie & 498,448 \\
28 & EuroMétropole de Strasbourg & 483,194 \\
49 & Grenoble-Alpes-Métropole & 450,494 \\
31 & Montpellier Méditerranée Métropole & 449,026 \\
43 & Rennes Métropole & 438,526 \\
20 & Métropole Grand Nancy & 259,813 \\
8 & Brest Métropole & 213,171 \\
\hline
\end{tabular}

what is the internal balance of powers between the metropolis, as a collective actor, and the mayors who may be reluctant to lose their autonomy? Third, which instruments will the metropolises use for planning? To address this question, the boundaries and substance of the planning documents and planning bodies of the metropolises will be analyzed. Finally, are planning issues really central in the new setting, or do other issues prevail, such as austerity or economic development? For this dimension, it is necessary to investigate the initial decisions taken by the metropolises, bearing in mind that we are still at a very early stage of the process.

As the series of reforms remains recent, has not been fully implemented and is little documented in the Englishlanguage literature, the present paper is a review paper. That is, the choice of references aims to reflect the main positions in the French academic debates. Statistical data and institutional information used for this paper are public, available from the national statistical office and the French Ministry of Interior. In particular, the statistics about municipalities and municipal groupings used in the paper have been extracted from the series of yearly reports of the Ministry of Interior published from 2000 to 2017. For the analysis of the rationales of the decisions, institutional literature is used. This paper's core sections are rather descriptive and discussion is left for the conclusion.

The next section aims to shed light on the movements of rescaling that have occurred in the long run. Since the first decentralization reform of 1982, the state has downscaled, handing over responsibilities to subnational governments, while cities have gained power. Disparities between the winners (metropolitan cores) and the losers (small and medium-sized cities, urban and rural peripheries) continued to increase. Planning objectives have moved from a redistributive approach (ensuring balanced territorial development) to a growth-oriented policy (enhancing metropolitan potentials). The third section focuses on the institutional design established by the current reform, strengthening regions and municipal groupings. Metropolises have been given exceptional powers with the introduction of asymmetrical devolutions, a fundamental change of the French model that previously focused on egalitarian, one-size-fits-all organization. The fourth section presents three metropolises with specific, tailor-made statuses: Lyon, Marseille and Paris. Conclusions will be drawn in the fifth section.

\section{Historical Background: Downscaling of the State, Upscaling of Metropolitan City-Regions}

\subsection{Downscaling of the National Level and the Reorientation from a Redistributive Spatial Policy to a Growth-Oriented and Spatially Differentiated Approach}

Neil Brenner argues that since the late 1970s, in Western Europe, "the long-entrenched primacy of the national scale of political-economic regulation has been destabilized and new scalar hierarchies of state institutional organization and state regulatory activity have been forged. Within these rescaled configurations of state power, major urban regions have become important geographical targets for a variety of far-reaching institutional changes and policy realignments designed to enhance local economic growth capacities" (Brenner 2004: 3). He identifies four stages of transformation. In the 1960 s, the Keynesian states pursued policies that aimed to reduce socio-economic inequalities through redistributive policies. In the $1970 \mathrm{~s}$, the focus moved towards endogenous growth. In the 1980s, urban locational policies emerged in a context of increased territorial com- 
petition driven by the global economy. From the 1990s, institutional reforms strengthened the metropolitan scale, which has inherited not only the burden of dealing with social and territorial disparities, but also the challenge of meeting global competition, a neo-liberal objective which tends to prevail over the others. The French evolution has followed a similar sequence.

Since the 1960s, France has addressed the metropolitan issue twice through national policies, soon interrupted by economic crises. In 1964, a policy promoted the métropoles d'équilibre (counterbalance metropolises) in their function of regional capitals. However, after the outbreak of the economic crisis of the mid-1970s, the policy was no longer followed. In the mid-1990s and early 2000s, collaborative city networks and "metropolitan collaborations" were supported in their joint endeavors. The 2008 crisis reoriented the agendas towards the support of specific economic sectors, eventually coming under the guise of sustainability. Regional planning has vanished, at least as seen from a national perspective (Geppert 2015).

The first attempt is characteristic of the Keynesian approach. In the 1960s, the policy of counterbalance metropolises was elaborated and implemented by the national government. Target cities were designated, following expert criteria (Hautreux/Rochefort 1963; Hautreux/ Rochefort 1964). For each city, metropolitan area organizations (organismes régionaux d'étude et d'aménagement d'aire métropolitaine, OREAM) were established under the authority of the national government's representative, to work out plans and strategies to support the development of metropolitan functions. The policy objective was the better spatial distribution of activities and people, particularly the reduction of the gap between "Paris and the French desert" (Gravier 1947). As regional capitals, the "counterbalance metropolises" benefited from ambitious investment programs in the fields of transportation, higher education, health, etc. The policy was typical of a centralized and Keynesian approach, redistributing the benefits of economic growth for better balanced regional development.

In the 1980s, shift towards endogenous growth was accompanied by the decentralization reform transferring planning competences to subnational governments. In the context of unemployment and economic crisis, urban locational policies prevailed. Cities pursued different strategies to remain competitive in the marketplace, in particular at the international level, where they attempted to attract increasingly mobile capital (Savitch/Kantor 2002).

In the 1990s, the national government granted some support to collaborative networks of cities (réseaux de villes). Established on a voluntary basis, réseaux de villes gathered together a collection of cities, sufficiently close to each other to combine their potential and overcome the handicap of their small size. Policy objectives switched from a re- distributive spatial approach to financial optimization and territorial competitiveness.

In the 2000s, the national government addressed the metropolitan issue again. Institutional reports analyzed metropolitanization as a response to globalization (CES 2003; DATAR 2003). Academic research showed that French cities ranked well in Europe with regard to culture and tourism but performed much less well in terms of economic functions (Rozenblat/Cicille 2003). The French government established a "call for metropolitan collaborations". Cities were invited to establish coalitions that would help them to enter European and global territorial competition (DATAR 2004). New constellations of actors, including non-institutional actors, were to prepare development strategies for broad metropolitan spaces. As financial support was soon insufficient, the policy delivered few results. However, analysis of the process shows a difference of focus between the national level, fostering urban locational policies, and the local actors, for whom public services, mobility, and local identities remain the key issues (Motte 2007; Geppert 2009).

While the national government has ceased to intervene directly, subnational governments have gained competences, autonomy and power. However, the emergence of the metropolitan scale is slow, not least because of the stratification of institutions inherited from long-entrenched positions.

\subsection{Crystallized Subnational Governments and Overlapping Responsibilities}

The lack of governing institutions and the difficulty of establishing appropriate governance arrangements at the metropolitan scale across which people live and work are not specific to France (Jouve/Lefèvre 2004). The French specificity is the number of subnational government tiers and their complex relations.

In the French millefeuille, the basic level of government is the municipality. In 1789 , the French National Constituent Assembly established 38,000 municipalities superimposed on the limits of the parishes. In 1884, they gained the status of local government. Today, their administrative boundaries remain very focused. The largest are Paris $(2,230,000$ inhabitants), Marseille $(855,000)$ and Lyon $(500,000)$. These three municipalities are subdivided in districts (arrondissements) each with a locally elected assembly and mayor. However, it is the overarching municipality that delegates competences and resources to them. Other French municipalities have a unique assembly and smallsized municipalities prevail: $97.5 \%$ of the municipalities have less than 10,000 inhabitants. Their average population is 1700 residents and more than half of the municipalities house less than 500 people (Chéron/Escapa 2015: 1). 
This small size entails a lack of financial resources and administrative capacity. Since 1971 (loi Marcellin), French governments have encouraged municipalities to merge. However, the mayors, well represented in the high chamber of the French Parliament, have been reluctant, arguing that French citizens are very attached to their municipalities. From 1971 to 2009, the number of municipalities was reduced by only 5\% (Sénat 2016: 9). In 2010 (loi RCT) and 2015 (loi Pélissard) new financial incentives were provided for new municipalities resulting from mergers implemented before the end of 2015. Indeed, in January 2016, the number of French municipalities for the first time dropped slightly below the symbolic number of 36,000 (AMF 2017: 1). However, so far, the overall picture has not changed significantly.

Incapable of merging municipalities, French governments established an additional institutional level for collaboration. Since 1890, municipalities may establish syndicates to deliver specific tasks, such as waste disposal or sanitation. Syndicates are financed by the contributions of constituent municipalities. Since 1959, other categories of municipal groupings have appeared, capable of imposing taxes, which grant them more resources and a higher level of autonomy from the constituent municipalities. They take over chosen competences from the constituent municipalities. In the course of time, tax-collecting municipal groupings have become quasi local governments, granted competences and resources but run by indirectly elected representatives, delegated from constituent municipalities. Since the 1960s, a diversity of legal statuses has developed, blurring the overall picture. The first urban communities, the most integrated category, were created in 1966. At the end of the 20th century, with 14,000 syndicates, 3000 taxcollecting groupings and 9000 isolated municipalities, the map of collaborative institutions was indeed complex. ${ }^{6}$

In 1999, a reform ${ }^{7}$ simplified the picture and established three categories of tax-collecting groupings. Communities of municipalities addressed the context of rural areas and small towns. They may be established by any group of municipalities, regardless of size, as long as they cover a continuous territory. Communities of agglomeration target medium-sized cities. They may be created by groups of municipalities bringing together a total of 50,000 inhabitants or more. Urban communities, the continuation of the category established in 1966, may be founded by groups of municipalities encompassing 500,000 inhabitants or more. The legal status of the grouping determines the competences transferred to the grouping and the taxes it may collect.

\footnotetext{
${ }^{6} \mathrm{http}: / /$ www.collectivites-locales.gouv.fr/bilans-statistiques-surlintercommunalite (March 28, 2017).

${ }^{7}$ Loi no 99-586 du 12 juillet 1999 relative au renforcement et à la simplification de la coopération intercommunale (loi Chevènement).
}

However, the implementation of the reform proved deceitful. The half-million French local elected representatives ${ }^{8}$ continued to defend their turf. With few exceptions, localism prevailed and the emergence of collective actors sharing a common vision did not occur (Cour des comptes 2005).

At the larger scale, two levels of subnational government compete. Counties were established during the French Revolution as a subdivision of the national administration. To erase the bedrock of localism, their boundaries were designed from scratch, ignoring the provinces from monarchal times. In 1871, the counties acquired the status of local government. Heirs of the Napoleonic administration, the 96 counties (excluding those overseas) have substantial budgets and staffing. Their culture is oriented towards managing public infrastructure and services more than towards carrying out new projects. Designed to enable any citizen to reach their administrative center in a half-day horse ride, they are today under-sized. Yet, their boundaries play an important role: for instance, municipal collaborations seldom cross these borders.

In 1982, the decentralization reform added a new level of subnational government, 22 regions. These regions have modest financial resources and lean staffing. It was mooted that regions would become the driver for planning projects, while counties would concentrate on management. However, this did not fit the French egalitarian tradition. No local government has primacy over another (non-tutelle). All tiers of local government hold competences in all domains, from education to planning. On top of their mandatory attributions, all levels of territorial government are competent to act in any domain if public interest is engaged (clause générale de compétence). The region Île-de-France is an exception in many dimensions: it is powerful, with a large budget and increased competences in planning, and it is challenged by powerful players, the national government which has increased control, the municipality of Paris, with its specific status, and a large number of insubordinate municipalities and municipal groupings.

The vertical allocation of roles has spread planning competences across levels (Figure 2). Planning documents follow a hierarchy. The strategic framework plan for the urban area (SCOT) provides guidelines for land-use plans (PLU) and sectoral documents (PLH, PDU). Regional plans are not binding for the next level, apart from in the region Île-de-France. Competences are spread across levels, with delimitations that remain fuzzy. Since the 1990s, overlapping roles, redundant policies, and complex financial partnerships have been key issues in French debates (DATAR 1993; Geppert 2014). A recurrent proposal is to suppress

\footnotetext{
${ }^{8}$ In 2016, France had 524,280 elected representatives in its municipalities, 4052 in the counties and 1880 in the regions (data: Ministry of Interior, Direction Générale des Collectivités Locales).
} 
State

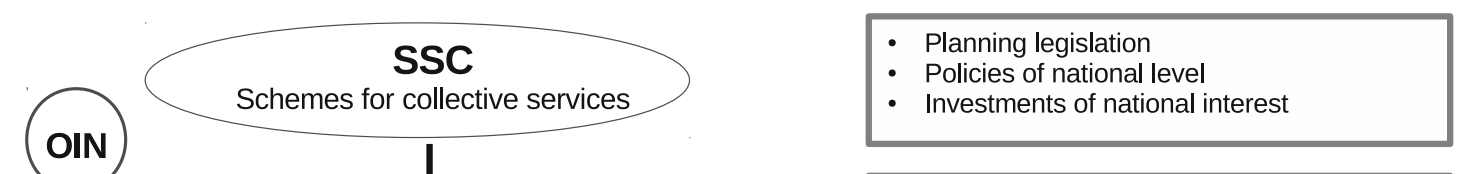

Regions

Counties

Municipalities

Individual actors

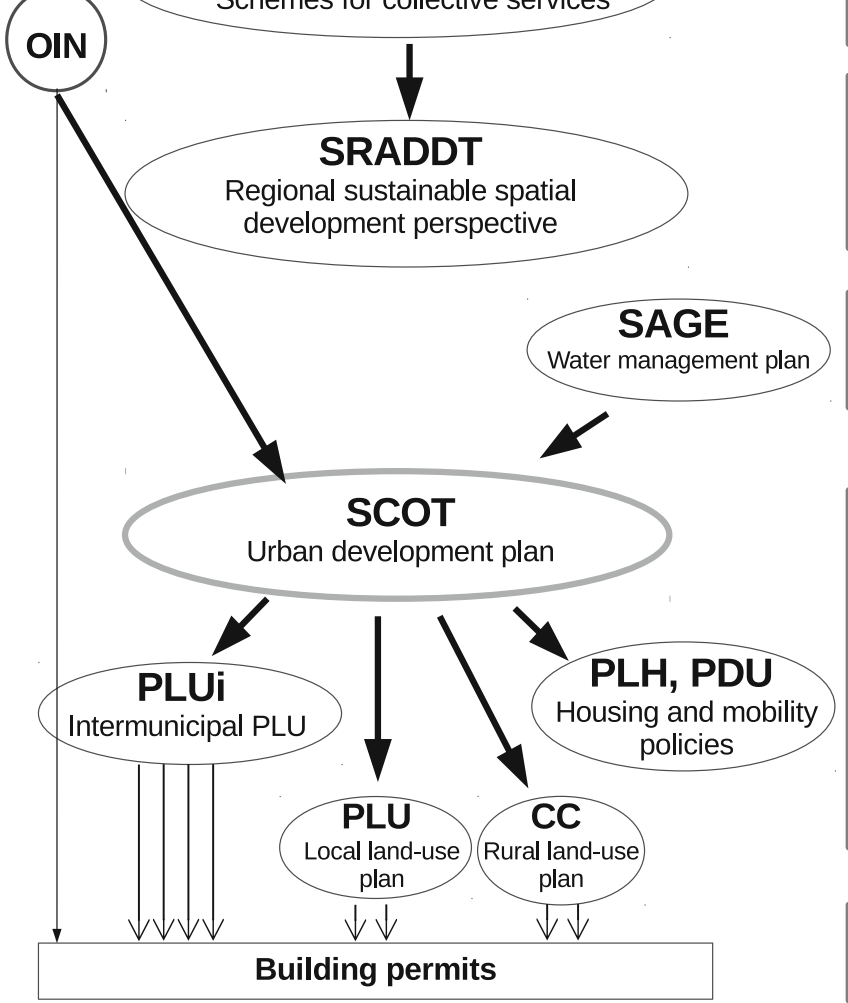

- Economic development

- Regional planning

- Sustainability

- Regional transportation

- Managing authority for European funds

- Rural planning

- Water management

- Most roads and infrastructures

Municipalities and municipality groupings:

- Planning documents

- Delivery of building permits

- Urban development

- Local transportation

- Social housing

- All local policies

Competences transferred to municipality groupings are no longer in the hands of individual municipalities

Legally binding relation:

$\rightarrow$ strategic guidelines $\rightarrow$ building code

Fig. 2 A simplified presentation of planning documents and competences in France (CC Carte Communale, OIN Opération d'Intérêt National, $P D U$ Plan de Déplacements Urbains, $P L H$ Programme Local de l'Habitat, $P L U$ Plan Local d'Urbanisme, PLUi Plan Local d'Urbanisme Intercommunal, SAGE Schéma d'Aménagement et de Gestion des Eaux, SCOT Schéma de Cohérence Territorialem, SRADDT Schéma Régional d'Aménagement et de Développement Durable du Territoire, SSC Schémas de Services Collectifs)

two levels, namely municipalities and counties (DATAR 1994; Attali 2008). However, local representatives are reluctant. As French politicians tend to cumulate mandates, they are well represented in the French Parliament. Consequently, institutional reforms end up trying to improve coordination between levels. Since 2003, when several tiers of government are involved in the same domain the law may designate one of them as coordinator. ${ }^{9}$ Another proposal is to specialize the levels, with spatial planning going to municipal groupings and regions which already hold most competences in this field.

\footnotetext{
9 French Constitution, article 72.
}

\section{The Institutional Reform, Between Rescaling and Re-Centralization}

Between 2010 and 2015, a series of laws ${ }^{10}$ modified the institutional architecture. Elaborated by two successive governments of different political orientation, the series of reforms changed the balance of power between subnational governments. Rescaling occurred: planning competences and resources that had been spread across all levels of government, from the municipalities to the national level, became concentrated at the level of municipal groupings, in particular the metropolises, and regions. In parallel, recentralization occurred: the national government withdrew

\footnotetext{
${ }^{10}$ Loi no 2010-1563 du 16 décembre 2010 de réforme des collectivités territoriales (Loi RCT); Loi no 2015-29 du 16 janvier 2015 relative à la délimitation des régions, aux élections régionales et départementales et modifiant le calendrier électoral; Loi no 2014-58 du 27 janvier 2014 de modernisation de l'action publique territoriale et d'affirmation des métropoles (Loi MAPTAM); Loi no 2015-991 du 7 août 2015 portant nouvelle organisation territoriale de la République (Loi NOTRe).
} 
Table 3 Evolution of the number of municipal groupings according to their type, 2002-2017, data as of $1^{\text {st }}$ January each year. (Source: Selected data extracted from the database BANATIC (Ministry of the Interior, Direction générale des collectivités locales), available on http://www.banatic.interieur.gouv.fr (March 8, 2017). Until 2012, transformation is slow and data are presented in a five-year cycle. Since 2012, because of the radical acceleration of changes, the table shifts to an annual basis)

\begin{tabular}{|c|c|c|c|c|c|c|c|c|}
\hline & 2002 & 2007 & 2012 & 2013 & 2014 & 2015 & 2016 & 2017 \\
\hline Métropole de Lyon (special status) & - & - & - & - & - & 1 & 1 & 1 \\
\hline Metropolises & - & - & 1 & 1 & 1 & 11 & 13 & 14 \\
\hline Urban Communities & 14 & 14 & 15 & 15 & 15 & 9 & 11 & 15 \\
\hline Communities of Agglomeration & 120 & 169 & 202 & 213 & 222 & 226 & 196 & 218 \\
\hline Communities of Municipalities & 2,032 & 2,400 & 2,358 & 2,223 & 1,903 & 1,884 & 1,842 & 1,019 \\
\hline New Town Syndicates & 8 & 5 & 5 & 4 & 4 & 3 & 0 & 0 \\
\hline $\begin{array}{l}\text { Coverage ( } \% \text { of French municipal- } \\
\text { ities belonging to one of the above } \\
\text { mentioned categories) }\end{array}$ & 73 & 91.1 & 96.2 & 98.3 & 99.8 & 99.8 & 99.9 & 100 \\
\hline
\end{tabular}

from the implementation of planning policies, but it took an authoritarian role in the design of institutional boundaries and powers previously left to subnational governments.

\subsection{A much Expected, yet Incomplete, Clarification of Roles}

Since the 1982 decentralization, the clarification of roles between regions and counties has been a recurring issue in French debates. A national commission investigating ways to foster growth recommended suppressing the counties (Attali 2008). However, the commission preparing the institutional reform proposed letting counties and regions merge into unique government units on a voluntary basis (Comité pour la réforme des collectivités locales 2009), and this is the solution implemented by the 2010 law. The only attempt at merger was undertaken in 2013 by the region Alsace together with its two counties. It failed due to a negative local referendum. To increase the political integration of regions and counties, a unique body of representatives (conseillers territoriaux) would sit in both assemblies. However, the new government backed out before such joint elections took place.

In the 2014 reform-of-the-reform, counties remained autonomous while the 22 regions were merged into 13 large regions (see Figure 1). Although granted more responsibilities in regional planning ${ }^{11}$ and economic development, attempts to specialize regions and counties remain unfulfilled. Their capacity to intervene in all fields (clause de compétence générale) was suppressed in 2010, restored in 2014 , and suppressed again in 2015 , but with many ex-

\footnotetext{
11 In particular, they will elaborate a regional plan, the schéma régional d'aménagement, de développement durable et d'égalité des territoires (SRADDET), that will be binding for the local level. This might be a turning point. Currently, the SRADDET is not binding (cf. Figure 2). But the new documents are at an initial stage of elaboration, also it is not possible to assess how regions will cope with this new competence.
}

ceptions to the rule. Leading territorial levels have been designated for certain domains: regions have this role for regional planning, economic development, transport coordination, environment, innovation and internationalization of firms. Counties have a strong role in social welfare and territorial solidarity.

At the local scale, municipal groupings should be large enough to "elaborate and conduct a project of spatial development, economic, ecological, educational and social". ${ }^{12}$ They should be more integrated, holding more competences. They should become more legitimate and their assemblies will be elected directly, in a joint municipaland-grouping election. Candidates for both assemblies are earmarked on the list (Frinault 2014). In 2014, the first election of this kind attracted the lowest participation in the history of municipal elections since 1958. The major shift lies in the definition of the composition of the municipal groupings, which had previously resulted from an agreement between the constituent municipalities. In the 2010 reform, the national government takes the lead: a representative of the government (préfet) is in charge of the elaboration of the scheme designating the municipal groupings of the county in question ${ }^{13}$. The scheme is presented to a committee of local representatives ${ }^{14}$ that needs to reach a majority of two-thirds to propose amendments. Performed after every municipal-and-grouping election, this exercise is recurring.

The objective of the reform is "to complete the coverage of the national territory by municipal groupings and to enlarge their framework". ${ }^{15}$ Consequently, since 2012, concentration has occurred (see Table 3). Mergers are reducing the number of groupings. The last isolated municipalities

\footnotetext{
12 Code Général des Collectivités Territoriales, art. L5217-1.

13 Schéma Départemental de Coopération Intercomunale, SDCI.

${ }^{14}$ Commission Départementale de Coopération Intercomunale, CDCI.

15 Projet de loi no 2010-1563 du 16 décembre 2010 de réforme des collectivités territoriales (Loi RCT): exposé des motifs.
} 


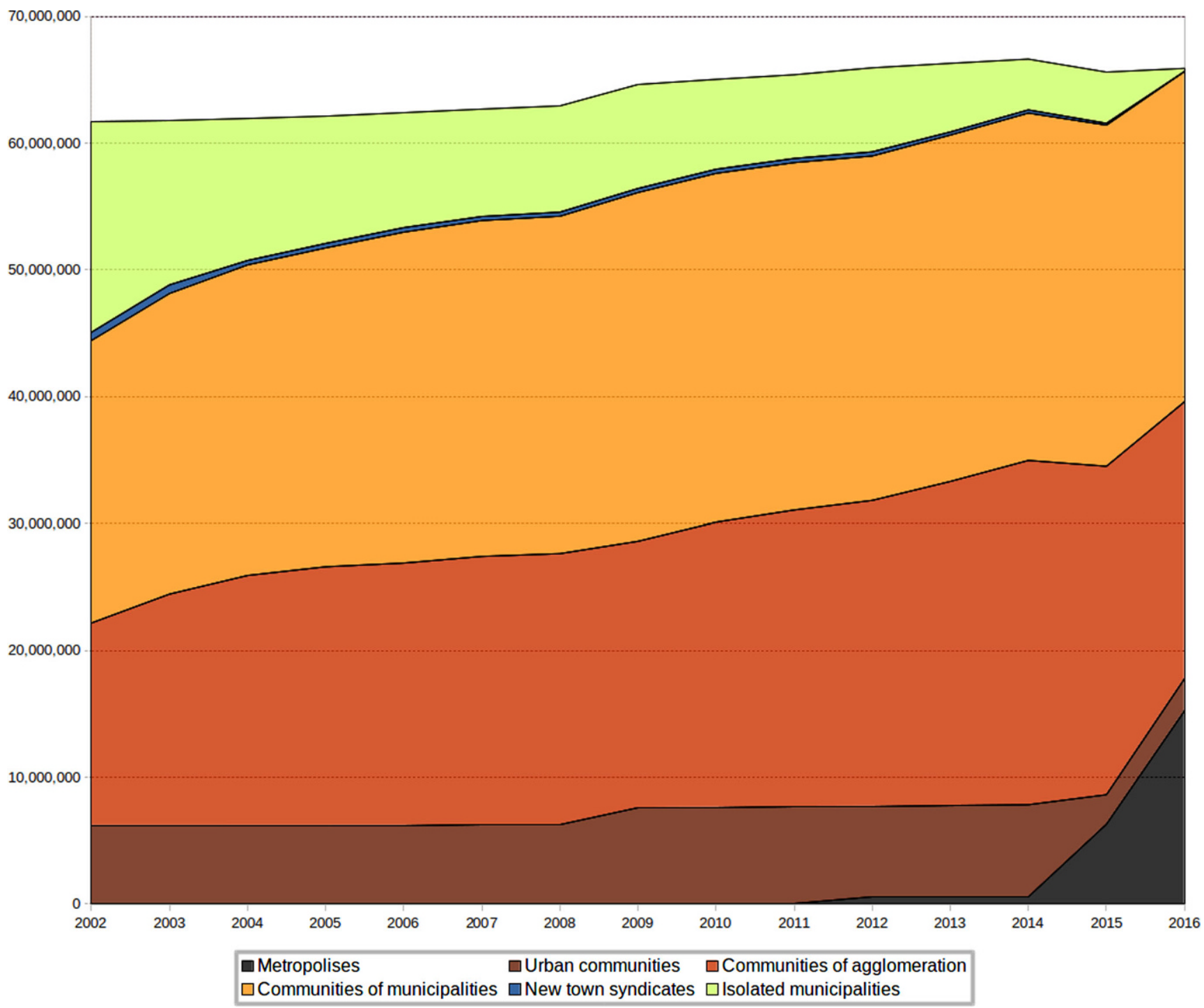

Fig. 3 Evolution of the number of inhabitants according to the type of municipal groupings, 2002-2016, data as of $1^{\text {st }}$ January each year. (Source: Data from the database BANATIC (Ministry of the Interior, Direction générale des collectivités locales), available on http://www.banatic.interieur. gouv.fr (March 8, 2017). Population based on the last census)

are disappearing and groupings are upgrading to more integrated categories: ancient urban communities have been promoted to the status of metropolises. New urban communities have appeared, while communities of municipalities and communities of agglomeration are merged into "XXL groupings", according to the nickname forged by the association of French Communities (ADCF 2016: 5). Very large groupings of more than 50, and even more than 100 municipalities, are numerous.

An overarching objective of this evolution, which appears in the motivation of all the bills since 2010, is the "rationalization" of French territorial organization, in order to avoid the current "loss of efficiency for public action and for the users of public services, high cost for the tax-payer, a lack of visibility for the citizen, and weariness for local representatives". ${ }^{16}$ The population breakdown confirms the fast implementation, integrating inhabitants in groupings of higher categories (Figure 3). Whether citizens will actually pay less tax appears dubious, and whether they will benefit from better services is uncertain. The Association of French Communities fears that "XXL communities" will be difficult to manage, they will increase the distance between the administration and the end-user, and local identities will be diluted (ADCF 2016: 29).

Institutional reforms increased the weight and strengthened the technical capacity of municipal groupings but did not establish them as the rightful government level. The

\footnotetext{
${ }^{16}$ Projet de loi no 2010-1563 du 16 décembre 2010 de réforme des collectivités territoriales (Loi RCT): exposé des motifs.
} 
Fig. 4 Metropolises, agglomerations and functional urban areas in January 2016. (Source: Data from the database BANATIC (Ministry of the Interior, Direction générale des collectivités locales), available on http:// www.banatic.interieur.gouv.fr (March 8, 2017). Population based on the last census)

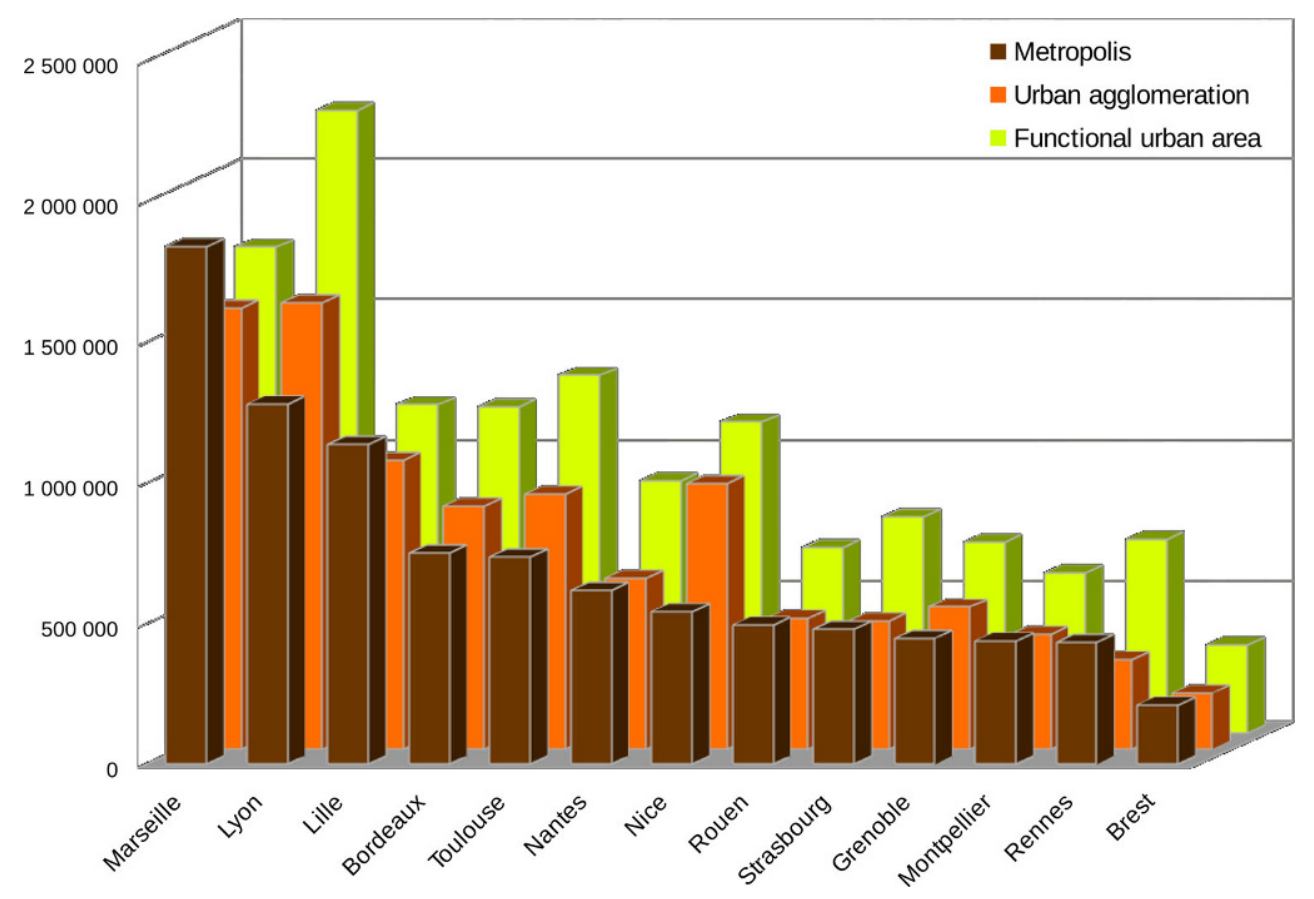

national government has achieved the position of arbitrator and gained control on the local level without engaging additional resources (Mongin 2010). On top of the existing categories, the reform established a new type of tax-collecting grouping dedicated to the largest urban areas, called metropolises (métropole).

\subsection{The Metropolis, a Super-Integrated Tax-Collecting Municipal Grouping}

The purpose of the metropolis, as for all municipal groupings, is to "elaborate and implement a project of spatial planning and of economic, ecological, educational, cultural and social development, in order to improve the competitiveness and the cohesion of their territory". ${ }^{17}$ The institutional innovation is that metropolises may benefit from competence transfers, not only from the municipalities, but also from other subnational governments, and eventually from the national level. This opens the way towards the more integrated management and planning of their territory.

Initially, the metropolis was a status for the largest French cities. In 2010, municipal groupings had to reach a threshold of 500,000 inhabitants or more to be eligible, equivalent to the thresholds for the existing category of urban community. The implementation of the reform encountered difficulties overcoming parochialism. On the one hand, cities that reached the threshold were satisfied with their status of urban communities and were not willing to

17 Code général des collectivités territoriales (CGCT), art. L. 5217-1. become metropolises as this entails reducing the power of the mayors in favor of the grouping. Since 2010, only one city (Nice) has opted for this status. On the other hand, there were cities below the threshold willing to become metropolises. However, they struggled to convince neighboring municipalities to join the alliance in order to reach the critical size.

The 2014 reform-of-the-reform marks an authoritative turn and legally designated eleven metropolises by transforming existing groupings, either urban communities (Bordeaux, Brest, Lille, Lyon, Marseille, Nantes, Strasbourg, Toulouse) or communities of agglomeration (Montpellier, Rennes, Rouen, Grenoble). The reform changed the conditions for becoming a metropolis, softening the criteria. The population threshold was lowered to municipal groupings of 400,000 inhabitants, the core of a functional urban area of 650,000 or more. Other criteria are added to suit cities that do not reach this threshold (Montpellier and Brest). Ultimately, today, the key lever is the agreement of the national government. In July 2016, Nancy $(266,000$ inhabitants) became a metropolis. In the end, instead of creating large alliances on the scale of broad urban areas, metropolises result in the increased integration of the urban cores of the municipalities, crystallizing pre-existing territorial structures (Figure 4).

How can these crystallized metropolises cope with planning their territories and their urban areas? As the metropolises have not enlarged the perimeters of the preexisting groupings, they have not led to a new generation of planning documents (SCOT). Also, the question of their capacity to influence the spatial planning of their urban 
Fig. 5 Summary of the analysis of metropolitan Schéma de Cohérence Territoriale (SCOT), December 2016

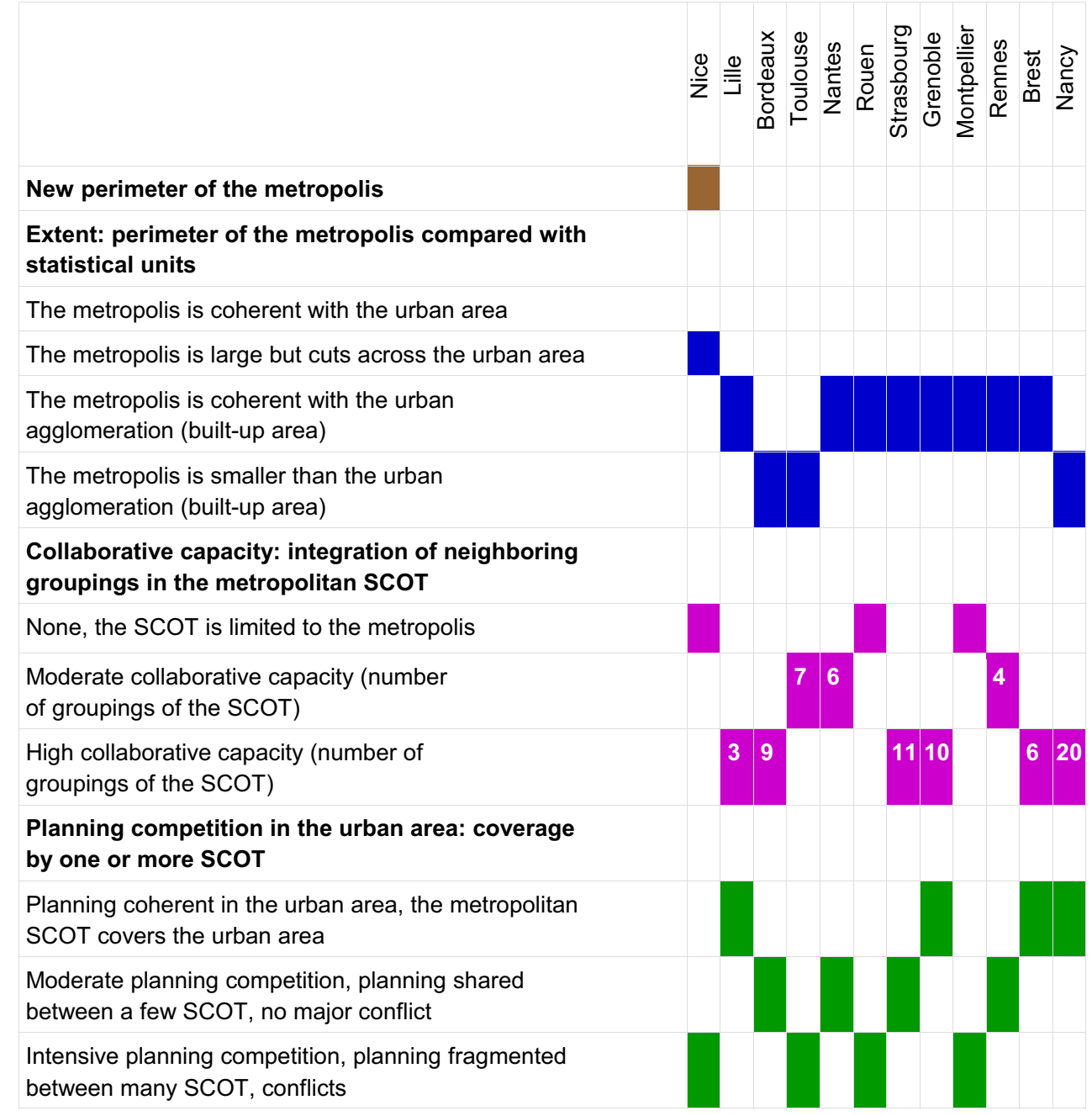

area has to be addressed based on the existing framework. It mobilizes three steps (Figure 5).

The first level of analysis is the territory of the metropolis itself: how far does it reach? In most cases, it roughly covers the built-up area represented by the urban agglomeration. Three metropolises do not reach this far (Bordeaux, Toulouse and Nancy), a situation inherited from local politics which tends to interfere with planning issues. For instance, in January 2016, Toulouse was confronted by a conflict in its south-eastern periphery, where mayors claimed an extension of the B metro line.

The second level is the sphere of influence of their planning document, the Schéma de Cohérence Territoriale (SCOT), which may be the joint endeavor of several municipal groupings. It provides an indication of the metropolises' capacity to collaborate with neighboring municipal groupings and plan together. Some remain isolated with their own SCOT (Nice, Rouen and Montpellier), whereas others have a moderate or high collaborative capacity. The quantitative approach (number of municipal groupings in the SCOT) needs to be seen in the context of local geography.
In the case of Brest and Lille, these few groupings cover the entire urban area.

The third level is the competition in the urban area outside the central SCOT. The coherence between perimeters (SCOT and urban area) was evaluated by the author to suppress minor differences. The level of fragmentation and the existence of planning conflicts were qualitatively assessed.

Confronting these elements, two ideal-types polarize the figure (see Table 4). The first ideal-type is a highly integrated and collaborative metropolis which has the capacity to reach beyond its limits and influence planning in the whole urban area. It has experience of long-established collaboration. Brest is a good example of such a voluntary approach to municipal collaboration and spatial planning. As early as 1974, in spite of its small size, Brest obtained the status of an urban community. Since then, its perimeter has not changed, but the grouping has taken over most competences from the municipalities, establishing, for example, common taxation. Its local land-use plan ("PLU Facteur 4") integrates policy documents on mobility, housing, and climate change that are usually elaborated separately. Plan- 
Table 4 Internal collaboration versus external competition in metropolitan planning

\begin{tabular}{|c|c|c|c|c|}
\hline \multirow[t]{5}{*}{$\begin{array}{l}\text { Internal collaborative } \\
\text { capacity }\end{array}$} & High & $\begin{array}{l}\text { Brest } \\
\text { Grenoble } \\
\text { Lille } \\
\text { Nancy }\end{array}$ & Strasbourg & - \\
\hline & Moderate & - & $\begin{array}{l}\text { Bordeaux } \\
\text { Nantes }\end{array}$ & $\begin{array}{l}\text { Rennes } \\
\text { Toulouse }\end{array}$ \\
\hline & None & - & - & $\begin{array}{l}\text { Montpellier } \\
\text { Nice } \\
\text { Rouen }\end{array}$ \\
\hline & & None & Moderate & High \\
\hline & & \multicolumn{3}{|c|}{ External planning competition in the urban area } \\
\hline
\end{tabular}

ning collaboration with the hinterland proceeds smoothly and has allowed the development of a common SCOT as well as a range of common planning endeavors fostered by a minimal collaborative structure (Pôle métropolitain $d u$ Pays de Brest).

The second ideal-type is the isolated metropolis, confronted with strong external competition in and for the planning of its urban area. Usually, such a configuration results from a high level of political and planning conflicts. Montpellier is a good example, with a long-lasting political conflict that started under the long series of mandates (19772004) issued by its contentious ex-mayor, Georges Frêche (1938-2010). One of the spatial issues at stake is that the small coastal resorts fear being swallowed up by the big city. Also, in spite of numerous attempts since 2005, they have never joined either the metropolitan grouping or its SCOT. Another example is Nice. With 550,000 inhabitants, it is the core of a much larger agglomeration of one million people at the Mediterranean, divided between municipal groupings attached to their core cities of Cannes, Antibes and Menton. Reasons for divisions are manifold, ranging from the personality of the mayor of Nice, Christian Estrosi, to planning conflicts on the localization of undesired equipment. Underbounded on the littoral, the metropolis reaches out far into the rural hinterland, until the Alps and their ski resorts. As a result, public transportation systems as well as the strategic planning documents (SCOT) of the respective cities remain fragmented. Meanwhile, the metropolis pursues a policy of territorial marketing, using its assets to attract tourism and business.

Intermediate configurations confirm there is a relationship between the capacity of the metropolis to convince its nearest neighbors to integrate a common framework (SCOT) and its capacity to reduce planning conflicts and competition in its broader environment. However, reduced competition does not necessarily mean convergence of views and initiatives. It is often obtained through implicit agreements of mutual respect between insiders and outsiders whose planning objectives are different.

\section{Three Specific Metropolises with Tailor-Made Statuses}

Each of the three major French cites has been assigned a specific, tailor-made status. They appear in very different contexts: the crystallization of a solid collaboration in Lyon, the authoritarian intervention of the national government in the conflict-ridden area of Aix-Marseille, a compromise between the numerous players of the Paris region.

\subsection{Lyon, a Small-Sized, Highly Integrated Government of a new Kind}

The urban community of Lyon has existed since 1969. Since its foundation, the agglomeration has grown as suburban municipalities have developed in juxtaposition to the core, but the urban community has not expanded proportionally. Narrower than its agglomeration, the municipal grouping comprises a solid alliance of municipalities, and is known for the strong involvement of non-institutional actors. The voices of economic stakeholders are heard in the cities' planning decisions. Through "ONLYLYON"18, all tiers of subnational government, the university, the tourist office, firms and representatives of the private sector campaign to market the city on the international stage. During the development of the 2014 law, the President of Grand Lyon, Gérard Collomb, and the President of the Rhône county, Michel Mercier, formed an alliance and obtained an institutional setting unique in France. Métropole de Lyon is a subnational government, replacing both the urban community and the county within its boundaries.

Métropole de Lyon is a powerful entity. With a comprehensive set of competences, it has gained full control over its territory. The shrunken Rhône county holds some 400,000 inhabitants in rural and suburban areas. This population is slightly better off than that in the core city and

\footnotetext{
18 ONLYLYON is both a brand and an international marketing program. Created in 2007 to build Lyon's international reputation, ONLYLYON brings together 26 public and private partners. This sort of public-private collaboration is rare in France.
} 
socially more homogeneous (Ambrogelly/Reynaud 2015). The new share of roles suits the metropolis, which is strengthened, as well as the county, which retains it light burden, in particular with regard to responsibilities in social welfare. However, in the longer run, this division between center and periphery leaves the margins of the agglomeration outside the dynamic development of the metropolis. In the end, it crystallizes the sharing of roles between the metropolitan economic driver and its residential periphery. A soft syndicate (pôle métropolitain) has been established to coordinate policies, but it has no competences and does not ensure solidarity between the two entities.

\subsection{Marseille, an Over-Sized Territory with Little Power}

Aggregated with the second pole of the region, Aix-enProvence, Marseille is the heart of an agglomeration of 1.5 million people. Territorial rivalries started when Aix was the capital of the realm of the counts of Provence (1189-1487), later attached to the French kingdom with a large degree of autonomy and its own parliament (1501-1790). Since the policy of counterbalancing metropolises, national governments have made several unsuccessful attempts to join in wedlock the two rival cities, situated some $30 \mathrm{~km}$ apart. There is no common interest between the small and privileged Aix-en-Provence, one of the richest cities in France, and the big Marseille, characterized by social and economic difficulties. The emergence of the metropolis took place in a context of conflicts (Douay 2013). In 2012, a representative of the national government, Laurent Théry, was nominated to support the process and moderate the negotiations between local stakeholders during the emergence of the new entity. During 2015, three consultants delivered visions of the metropolitan territory, elaborating on its potentials. A broad consultation was held in the first months of 2016 with the various stakeholders with the aim of developing a common vision and a shared project (Théry 2016). However, the boundaries of the metropolis were imposed on the local actors by the national government.

With over $3000 \mathrm{~km}^{2}$, Métropole Aix-Marseille-Provence is by far the largest French grouping. It is very broad, six times the size of Lyon métropole, and four times the size of Métropole du Grand Paris. Its 1.8 million inhabitants, as well as its territory, are diverse, socially, economically, and geographically. The change of institutional design will be gradually implemented over a long period of transition. Competences will be progressively transferred to the metropolis from the county (2017) and the municipalities (2018). The former municipal groupings will lose their status as legal entities. However, they will survive inside the metropolis in the form of "territorial councils", to which the metropolitan assembly will delegate the competences of the six former municipal groupings. As a result, the model appears federative and the territorial councils remain the central players. By 2020, a charter will be elaborated to define the sharing of roles between the metropolitan assembly and the territorial councils. Given the divergent interests and the strong local identities involved, it is very likely that the powers of the metropolitan level will remain weak.

\subsection{Grand Paris, a Metropolis for the Core of the City- Region with a Double Level of Governance}

The municipality of Paris houses about 2.5 million inhabitants. It is the heart of a built-up agglomeration of 10.5 million people spread over 432 municipalities. The broader urban area covers the whole region of the Île-de-France. The structure is highly monocentric, with a rich and compact centre (the municipality of Paris) surrounded by two rings of decreasing urban density that encompass deprived areas inherited from the large housing schemes of the twentieth century, new towns, and privileged enclaves.

All government levels participate and compete in governing the capital region. The national government pursues planning endeavors of national interest in the capital region. Currently, the project of the Grand Paris Express, a metro ring linking the suburbs of the capital, is being implemented by a national agency, the Société du Grand Paris (SGP). It will significantly change the structure of greater Paris. The planning system differs from the national structure. The regional masterplan (SDRIF) is elaborated by the region but needs the approval of the national level. It is binding for planning documents elaborated by municipal groupings and municipalities. The region Île-de-France is responsible for public transportation, run through a syndicate (STIF). Services are delivered by a nebula of syndicates in various configurations, inherited from a long history. Water sanitation is the task of a syndicate including the four central counties (SIAAP). It covers the needs of $75 \%$ of the region's population, and more remote territories have their own organizations. Water distribution is the responsibility of the SEDIF, a syndicate of 149 municipalities - but not Paris - that supplies water to 4.5 million people. Waste sanitation is performed by the SYTCOM, serving half of the region's population on behalf of 84 municipalities (Syndicats urbains d'Ile-de-France 2014).

Since the times of the monarchy, national governments have distrusted the insurrectionist city and keep it under surveillance. One aspect of this control is that Paris was the only French municipality forbidden to participate in tax-collecting municipal groupings. However, in 2009, Paris initiated a soft collaboration with the surrounding municipalities through a syndicate, Paris métropole, trying to reach beyond the Boulevard Périphérique and increase its power against two competitors, the national government and the region 
Île-de-France (Desjardins 2010). The vision promoted by Paris métropole is rather federal, leaving most power to the local level and aiming to cover the whole urbanized area: the status of the syndicate gives all local governments the option to join. Indeed, since 2009, Paris métropole has kept expanding. Today, it is home to almost 10 million inhabitants.

The bill presented in 2013 was inspired by this approach. It targeted a broad territory, with rather federative governance where municipal groupings would play the key role. However, Members of Parliament who wanted to defend the municipalities against the groupings opposed the bill (Lacoste 2013). In the end, a different project emerged, with a much narrower territory and more integrated governance. The Métropole du Grand Paris has some 7 million inhabitants. This encompasses the dense part of the agglomeration (Paris and the first ring of suburbs). 12 new entities designated by law (Etablissements Publics Territoriaux, EPT) replace the former municipal groupings, including formerly isolated municipalities.

The Etablissements Publics Territoriaux are a legal entity, but they do not have the right to collect taxes: the only tax-collecting group is the metropolis. Potentially, it is a very powerful player. With a budget of some 3.5 billion euros it may compete with the region Île-de-France, which manages some 5 billion euros for a much wider territory. However, financial resources are redistributed based on the division of tasks between the metropolis and the Etablissements Publics Territoriaux. Until a "pact" has been elaborated to define the competences of metropolitan interest, the birth of the metropolis should be financially neutral for the municipalities and groupings. As a result, in 2016, after redistribution the Métropole du Grand Paris was left with 55 million euros, about $1.5 \%$ of the total resources. For the moment, the metropolis elaborates strategic guidelines, but the actual projects are implemented at the local level. In the future, the metropolis will have to cope with various competitors challenging its emergence, both outsiders - the national government and the regional council - and insiders - municipalities and EPT.

\section{Conclusion}

After three decades of decentralization, the French culture still bears the footprint of the powerful and centralized administrative system of Napoleonic times, when all local decisions required the authorization of the representative of the national government (le préfet) (Geppert 2015). When the attempt to open the way to voluntary transition failed, the national government took action and forced the creation of metropolises. An even more authoritarian approach has been adopted in the forced merger of regions. With this move, the national government regained its determinant role as the architect of territorial institutional design, forging "new scalar hierarchies of state institutional organization and state regulatory activity" (Brenner 2004: 3). An important dimension of these "far-reaching institutional changes" (Brenner 2004: 4) is that the new institutional design breaks with the French egalitarian model, introducing tailor-made arrangements and asymmetrical devolutions of competences transferred from other tiers of government. Lyon is the most advanced example. In this case, one level of subnational government (the county) disappears.

However, implementation of the reform has been limited by the crystallization of the preexisting institutional design. In the voluntary phase of the process (2010-2013), city-regions proved incapable of overcoming political and territorial rivalries. The only exception, Nice, is finalizing an alliance with its inland - but cannot integrate its immediate neighbors along the Mediterranean coast. This has opened the way to an authoritarian phase, where national government imposes the transformation of existing municipal groupings. In two exceptions, the metropolises have absorbed more municipal groupings so they have either disappeared (Marseille) or been transformed (Paris). In both cases, a two-tier organization has been adopted, taking a more fragile form in the case of the Marseille "territorial councils" and more substantiated with the Etablissements Publics Territoriaux in Paris. The final definition of what is a matter of metropolitan interest, under common governance, and what is left to local policies, will emerge during the present period of transition established until 2020. This moderates the extent to which the national government can define the rules of the game: the local level is striking back using various forms of resistance, be it lobbying in Parliament or when implementing the legislation. Similar evolutions have been seen elsewhere, be it in Poland where a failed attempt in 2003 was followed by a relaunch in 2015 , or in Australia, where the metropolitan reform of 2013 was abandoned in 2015.

Trajectories and choices differ from one metropolis to another. Politics play a role. The lobbying undertaken by the mayors of cities under the initial threshold has succeeded and changed the nature of the reform, initially intended to foster the emergence of large city-regions and finally reduced to the strengthening of highly integrated municipal groupings. The mayors of the cities who succeeded in lobbying during elaboration of the reform-of-thereform are prominent members of the governing socialist party: Gérard Collomb in Lyon, Philippe Saurel in Montpellier, François Cuillandre in Brest. In addition to their political obedience, they have private relations with members of the national government. In contrast, the forced marriage of Marseille and Aix-en-Provence was decided by a left-wing government in opposition to a right-wing mayor, 
Jean-Claude Gaudin. Locally, the existence of a collaborative culture facilitates the process. This usually results from a long history, in which infrastructure and urban projects have played a positive role and planning conflicts, such as waste incinerators, have hampered the process. Longentrenched groupings, such as Brest or Lyon, proved themselves on a voluntary basis in the process. However, the existence of a particular political leadership is another factor that has allowed conflicts to be overcome, for instance in Nice or Montpellier.

French metropolises remain undersized, compared with the development of metropolitan areas. City-regions emerge from this reform divided between core-cities and peripheries. In the case of Lyon, these peripheries are well-off. Usually, core-cities are richer. In all cases, they concentrate employment and economic poles. As a result, the active core is disconnected from the residential and rural peripheries. This fits the scheme observed by Brenner (2004), where institutional reforms lead to the strengthening of the most dynamic areas, leaving the rest of the territory to its destiny. The 2010 law proposes the soft framework of pôle métropolitain for collaborations between neighboring institutions. However, these syndicates depend on the goodwill of all parties, and therefore work best in places where relations are smooth and territorial inequalities moderate, like around Brest.

In most metropolises, policy objectives tend to shift from spatial planning to territorial competitiveness. Local choices implemented so far by the metropolises confirm this orientation. Metropolitan planning has not been relaunched. Metropolitan policies are much oriented towards economic development and place-branding. Redistribution mechanisms are not better in the metropolis than in regular municipal groupings. The first transfers of competences from the counties, enacted in December 2016, show that metropolises tend to opt for the less costly ones. The most central issue for spatial planning, the transfer of road infrastructure, remains under negotiation.

Finally, metropolises imply a democratic issue. Municipalities are well appropriated by French citizens, as demonstrated by participation in municipal elections, some 10 points higher than participation in elections of other tiers. Although tied together by daily connections, metropoli$\tan$ spaces remain for many somewhat abstract. Metropolitan assemblies will be elected during the municipal elections, through earmarking candidates from municipal lists for a predefined number of seats. This system makes them representatives of their municipality rather than carriers of a metropolitan vision. There is a risk of that assemblies may balance local stakes rather than building a metropolitan project. Alongside elected assemblies, metropolises have two consultative bodies. A Metropolitan Conference gathers together the mayors of all the municipalities, to coor- dinate their policies. This may help to harmonize policies, but may also become the floor of parochialism. A Development Council comprises the freely chosen representatives of economic, social, cultural, educational, scientific, and associative milieus. It may be the vehicle for participative processes as well as for interest groups. It is too early to see what this governance model will deliver, but the new metropolises might turn out to be a democratic black box.

\section{References}

ADCF - Assemblée des Communautés de France (2016): Grandes communautés: de l'exception à la généralisation? Paris.

Alvergne, C.; Musso, P. (2008): Les grands textes de l'aménagement du territoire et de la décentralisation. Paris.

Alvergne, C.; Taulelle, F. (2002): Du local à l'Europe. Les nouvelles politiques d'aménagement du territoire. Paris.

Ambrogelly, M.-P.; Reynaud, J.-P. (2015): Action sociale: des indicateurs pour le Rhône et la Métropole de Lyon. Lyon. = INSEE Flash Rhône-Alpes 18.

AMF - Association des Maires de France et des Présidents d'Intercommunalité (2017): La France est passée sous la barre des 36000 communes, à 35945. http://www.amf.asso.fr/document/ index.asp?doc_n_id=14255 (April 11, 2017).

Attali, J. (2008): Rapport de la Commission pour la libération de la croissance française: 300 décisions pour changer la France. Paris.

Brenner, N. (2004): New State Spaces. Urban Governance and the Rescaling of Statehood. Oxford.

CES - Conseil Economique et Social (2003): Métropoles et structuration du territoire. Avis du 9 avril 2003, rapporteur J.C. Bury.

Chéron, S.; Escapa, C. (2015): Plus d'une commune métropolitaine sur deux compte moins de 500 habitants. Paris. = INSEE Focus 52.

Comité pour la réforme des collectivités locales (2009): Il est temps de décider. Rapport au Président de la République. Paris.

Cour des comptes (2005): L'intercommunalité en France: rapport au Président de la République suivi des réponses des administrations et des organismes intéressés. Paris.

DATAR - Délégation interministérielle à l'aménagement du territoire et à l'attractivité régionale (1993): Débat National pour l'aménagement du territoire. Document Introductif. Paris.

DATAR - Délégation interministérielle à l'aménagement du territoire et à l'attractivité régionale (1994): Débat National pour l'aménagement du territoire. Document d'Etape. Paris.

DATAR - Délégation interministérielle à l'aménagement du territoire et à l'attractivité régionale (2003): Pour un rayonnement européen des métropoles françaises: éléments de diagnostic et orientations. Paris.

DATAR - Délégation interministérielle à l'aménagement du territoire et à l'attractivité régionale (2004): Pour un rayonnement européen des métropoles françaises - Appel à coopération. Paris.

Desjardins, X. (2010): La bataille du Grand Paris. In: L'information géographique $74,4,29-46$.

Douay, N. (2013): Aix - Marseille - Provence: accouchement d'une métropole dans la douleur. In: Métropolitiques du 18 décembre 2013. http://www.metropolitiques.eu/Aix-Marseille-Provence. html (March 10, 2017).

European Commission (1997): The EU compendium of spatial planning systems and policies. Luxembourg.

Frémont, A. (2005): Géographie et action, l'aménagement du territoire. Paris.

Frinault, T. (2014): Avancées et verrouillages: la métropolisation au milieu du gué. In: Métropolitiques du 27 janvier 2014. http:// www.metropolitiques.eu/Avancees-et-verrouillages-la.html (March 10, 2017). 
Geppert, A. (2009): Polycentricity: can we make it happen? From a concept to its implementation. In: Urban Research and Practice $2,3,251-268$.

Geppert, A. (2014): France, drifting away from the "regional economic" approach. In: Reimer, M.; Getimis, P.; Blotevogel, H.H. (eds.): Spatial Planning Systems and Practices in Europe. A Comparative Perspective on Continuity and Changes. London, 109126

Geppert, A. (2015): Planning without a spatial development perspective? The French case. In: Knaap, G.; Nedovic-Budic, Z.; Carbonell, A. (eds.): Planning for States and Nation/States: A TransAtlantic Exploration. Cambridge, MA, 381-410.

Gravier, J.-F. (1947): Paris et le désert français. Paris.

Hautreux, J.; Rochefort, M. (1963): Le niveau supérieur de l'armature urbaine française. Paris.

Hautreux, J.; Rochefort, M. (1964): La fonction régionale dans l'armature urbaine française. Paris.

Jouve, B.; Lefèvre, C. (eds.) (2004): Métropoles ingouvernables: les villes européennes entre globalisation et décentralisation. Paris.

Juillard, E.; Nonn, H. (eds.) (1976): Espaces et régions en Europe occidentale: Structures et dimensions de régions en Europe occidentale. Paris.

Lacoste, G. (2013): La Métropole du Grand Paris, intégration ou confédération? In: Métropolitiques du 9 septembre 2013. http://www. metropolitiques.eu/La-Metropole-du-Grand-Paris.html (March $10,2017)$.
Mongin, O. (2010): Le Grand Paris et la réforme des collectivités territoriales. Quel retour de l'État? In: Esprit 3, 120-131.

Motte, A. (ed.) (2007): Les agglomérations françaises face aux défis métropolitains. Paris.

OECD - Organisation for Economic Co-operation and Development (2014): OECD Regional Outlook 2014. Regions and Cities: Where Policies and People Meet. Paris.

Rochefort, M. (2000): Dynamique de l'espace français et aménagement du territoire. Paris.

Rozenblat, C.; Cicille, P.; (2003): Les villes européennes: analyse comparative. La Documentation Française. Paris.

Savitch, H.V.; Kantor, P. (2002): Cities in the International Marketplace: The Political Economy of Urban Development in North America and Western Europe. Princeton.

Sénat (2016): Rapport d'information $n^{\circ} 563$ fait au nom de la délégation aux collectivités territoriales et à la décentralisation (1): les communes nouvelles, histoire d'une révolution silencieuse. Raisons et conditions d'une réussite, Par M. Christian MANABLE et Mme Françoise GATEL, Sénateurs. http://www.senat. fr/rap/r15-563/r15-563_mono.html (April 11, 2017).

Syndicats urbains d'Ile-de-France (2014): Memorendum des Grands Syndicats Urbains d'Ile-de-France à l'intention de la Mission de Préfiguration de la Métropole du Grand Paris. Paris.

Théry, L. (ed.) (2016): La métropole par le projet. Aix-en-Provence. 